\title{
Factory automation programme ready to fly
}

Tokyo. The Intelligent Manufacturing System (IMS) project - a global effort to develop the factory of the future - looks set to finally take off this year, five years after it was first proposed by Japan.

The IMS international steering committee, which includes representatives of Japan, the United States, Canada, Europe and Australia, will shortly release a final report recommending launch of a full-scale programme that will run for ten years. Although the report does not include a total cost estimate for IMS, officials close to the programme say it may involve a government-industry investment of as much as US\$4 billion.

Over the past year, a total of 73 companies and 67 universities and research institutes in the five partner regions have participated in 6 test case projects to check the feasibility of a full-scale IMS programme (see Nature 362, 97; 1993). Although some problems have been encountered, the international steering committee concludes in the final draft of its report that IMS can be a "win-win opportunity" and a "catalyst" for "unique" international collaboration in industrial research.

IMS was proposed in 1989 by Hiroyuki Yoshikawa, then dean of the faculty of engi-

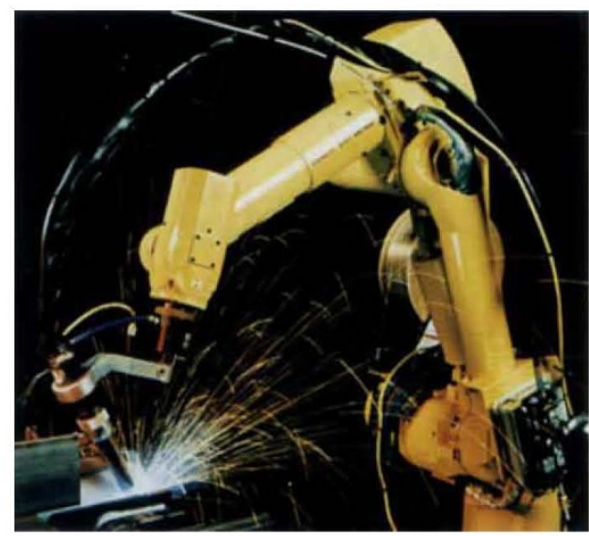

Better robots through global collaboration? neering of Tokyo University, with the backing of the Ministry of International Trade and Industry (MITI). But the proposed central administration by Tokyo received a cool reception in Washington and Brussels, and after several years of discussions the project has evolved along far more decentralised lines, similar in structure to the European computer research programme ESPRIT.

Different funding mechanisms were used in each part of the world for the test projects. In Japan, for example, an IMS centre supported by private companies and MITI provided funds, while the telecommunications and information technology directorate of the European Commission supported some European partners.

Japan's original proposal called for an investment of about $\$ 1$ billion in the IMS project. The European Community has more recently estimated that about 4 billion ECU (US $\$ 4$ billion) will be required for the proposed ten-year project. But the US Department of Commerce balked at including such a large figure in the final report.

Having looked at the test projects, the steering committee concludes that effective international collaboration was achieved among first-class companies and universities in highly competitive research. "Surprisingly, language and cultural differences did not prove to be a barrier. Rather, these differences added value to the projects and improved their quality in terms of scope, technical content and organization," says the draft.

However, international travel and telecommunications costs proved to be a major burden, constituting 25-30 per cent of project costs. And, even with growing use of computer networks and e-mail, the steering committee expects these overheads to remain high in the full-scale programme, particularly in the initial set-up stage. Intellectual property rights remain a problem despite extensive guidelines prepared by an IMS committee - and held back some of the projects, as did the different funding mechanisms in each region.

Yuji Furukawa, dean of the faculty of engineering of Tokyo Metropolitan University, who represented Japan on the IMS international technical committee and also seconded for Yoshikawa on the steering committee, expects 3 or 4 of the test case projects to continue into the full-scale programme, and 3 or 4 more may be added. He says they are likely to cover three broad themes: short-term development of global manufacturing techniques; clean "environment-friendly" manufacturing technology; and human and cultural aspects of global manufacturing.

One test case likely to be part of the fullscale programme is "Globeman 21 " led by British Aerospace, which aims at determining the most efficient ways of running global manufacturing organizations that have supply chains in different time zones and a range of participating enterprises. Similarly, a project led by Allen-Bradley of the United States with 32 partners in all regions seems set to continue, as does one headed by Mitsubishi Electric of Japan.

However, "clean manufacturing in the process industry" led by ICI in Britain, has ended after failing to win funding from the European Community.

The Japanese have several projects in a domestic IMS programme, which they hope will become part of the full-scale international project. One is a project led by Fuji Electric to develop better computer systems for manufacturing control. According to
Furukawa, whose university is a partner in the project, many US and European companies are very interested in this area which includes concepts such as "agile manufacturing" and "bionic manufacturing". In the latter, the aim is to imitate biological information/production systems, like DNA.

Japanese robot maker Fanuc is leading a project to develop better assembly robots. And Kajima construction company and Hitachi Zosen, a shipping company, are working on "metamorphic" carrying devices that can flexibly adjust to pick up objects of various shapes and sizes.

The full-scale international programme should get underway towards the end of this year, says Furukawa, after the governments of the participant countries and regions have agreed on new terms of reference. The report recommends that the project should be managed by an international steering committee, while regional secretariats and a small inter-regional secretariat will disseminate information, help form consortia, and facilitate review and selection of projects.

David Swinbanks

\section{Fatal blast at experimental reactor}

Paris. An explosion killed a technician from the French Atomic Energy Commission (CEA) last week while he was decommissioning an experimental reactor at CEA's research centre at Cadarache in southern France.

The technician, René Allègre, was killed by a blast which caused a $300 \mathrm{~m}^{2}$ concrete floor to collapse, also injuring three engineers and another technician, one seriously.

The explosion occurred as they were cleaning residual sodium, slightly contaminated with caesium 137 and tritium, from the cooling circuits of France's first experimental fast-breeder reactor, Rapsodie, which entered service in 1967 and shut down in late 1982.

Early speculation centred on the hypothesis that a violent reaction of sodium with air or water might have caused the explosionthe safety of using sodium as coolant in fast breeders remains controversial. But the first analyses of the accident suggest that hydrogen, produced by the reaction of an alcoholcontaining cleaning fluid with the sodium, built-up with unexpected speed.

The French nuclear installation safety authority (DSIN) has rated the accident at two, on a scale of six. Samples taken around the site suggest that no radioactivity escaped beyond the immediate vicinity of the installation, according to the authority.

Declan Butler 